RICYDE. Revista Internacional de Ciencias del Deporte doi: $10.5232 /$ ricyde

Rev. int. cienc. deporte

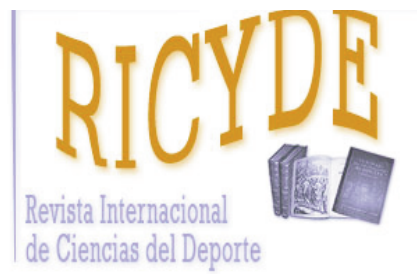

RICYDE. Revista Internacional de Ciencias del Deporte VOLUME XIII - YEAR XIII

Pages:331-355 ISSN:1885-3137

Issue 50 - October - 2017

\title{
Unfavorable critical moments and way of facing them from the futsal coach's point of view through ad hoc questionnaire \\ Momentos críticos desfavorables y manera de afrontarlos desde la perspectiva del entrenador de futsal a través de un cuestionario ad hoc
}

Cesar Méndez-Domínguez, Miguel A. Gómez-Ruano, Luis M. Ruiz-Pérez, Yixiong Cui

Facultad de Ciencias de la Actividad Física y del Deporte. Universidad Politécnica de Madrid. España

\begin{abstract}
In this study, a designed ad hoc questionnaire was constructed and validated to investigate the opinion of coaches about the concept of unfavorable critical moment in futsal, and the coincident use of goalkeeper as an outfield player strategy (5vs4) with that critical moment, which is a decisive step towards theoretical and methodological convergences. A total of 129 coaches belonging to teams of divisions 1st, 2nd and 2nd B participated in the questionnaire, which was validated by the judgment of experts thru calculating the content validity through the Aiken's V coefficient (Aiken, 1980, 1985). The results of the qualitative study revealed the importance that futsal coaches give to the maximum difference of 2 goals, and to the last 8 min of the game as maximum exponents of criticality, also to the importance of the 5th accumulated foul as a precipitant factor of an unfavorable critical moment in maximum equality matches. In addition, coaches manifested that interactive effects of score-line, remaining time and accumulated fouls could be the trigger of unfavorable critical moments, and using the goalkeeper as an outfield player strategy is a common practice to solve these situations. The values obtained in 19 of the 20 items $(V>0.90)$ attest that the content of the questionnaire is valid to show that the sample of futsal coaches understands the concept of criticality. The implications of the study contribute to a more specific knowledge of the futsal game and at the practical level the possibility of using this information to establish training objectives related to different stress conditions.
\end{abstract}

Key words: Coaching; expert coach assessment; validity content; criticality, goalkeeper as an outfield player; futsal.

\section{Resumen}

A través de la construcción y validación de un cuestionario diseñado ad hoc se trató de investigar el pensamiento del entrenador relacionado con el concepto de momento crítico desfavorable en futsal, y la utilización del portero-jugador (5vs4) coincidente con el momento crítico, como un paso decisivo hacia convergencias teóricas y metodológicas. Un total de 129 entrenadores pertenecientes a equipos de $1^{\mathrm{a}}, 2^{\mathrm{a}}$ y $2^{\mathrm{a}} \mathrm{B}$ participaron en el cuestionario, que fue validado mediante el juicio de expertos calculando el índice de validez de contenido a través del coeficiente Aiken's V (Aiken,1980, 1985). Los resultados del estudio cualitativo revelan la importancia que otorgan los entrenadores de futsal a la diferencia máxima de 2 goles y a los últimos 8 minutos del partido como máximos exponentes de la criticidad, y a la importancia de la 5 a falta como factor precipitante de un momento crítico desfavorable en partidos de máxima igualdad. Además, muestran acuerdo en que los efectos interactivos de marcador, tiempo y faltas pueden ser el desencadenante de los momentos críticos desfavorables, y que es una práctica común el decidir afrontarlos con la utilización del procedimiento portero como jugador de campo (5vs4). Los valores obtenidos en 19 de los 20 ítems (V>0.90) atestiguan que el contenido del cuestionario es válido para demostrar que la muestra de entrenadores de futsal entiende el concepto de criticidad. Las implicaciones del estudio aportan la contribución esencial del entrenador para un conocimiento más específico del juego, y a nivel práctico la posibilidad de utilizar esta información para establecer objetivos de entrenamiento relacionados con las diferentes condiciones de estrés.

Palabras clave: Entrenamiento; valoración de expertos; validez de contenido; criticidad, portero como jugador de campo; futsal. 
Méndez-Dominguez, C.; Gómez-Ruano, M.A.; Ruiz-Pérez, L.M.; Cul, Y. (2017). Unfavorable critical moments and way of facing them from the futsal coach's point of view through ad hoc questionnaire. RICYDE. Revista internacional de ciencias del deporte, 50(13), 339-355. https://doi.org/10.5232/ricyde2017.05002

\section{Introduction}

$\mathrm{T}$ he coach's opinion is a rising subject that is causing interest in the sport science community. In the training environment, to determine the importance that the coach gives to different performance factors and training contents (Abraham, Collins \& Martindale, 2006; Côte \& Gilbert, 2009; Leite, Coelho \& Sampaio, 2011). In a competitive environment, to investigate the role and influence of the coach's behavior on his players during competition (Smith \& Cushion, 2006). These investigations will provide greater knowledge of what coaches think in order to develop highly specialized training (Serrano, Shahidian, Sampaio \& Leite, 2013).

Currently, within the analysis of the game, the important line of research related to the Critical Moment of play (hereinafter CM), based on the dynamics of time and score-line, has been increasing and trying to identify the psychological impact that certain events and moments generate in the performance of teams and players, and their impact on the final outcome (Carvalho \& Araujo, 2013). Qualitative studies lack in giving a more focused and representative understanding of this phenomenon at a general level (Crust \& Nesti, 2006). Moreover, in the field of futsal few studies were found regarding the point of view of coaches on critical moments. Therefore, it is useful to utilize the basketball coach's standpoint on this topic to contextualize the study.

The perspective coaches have of the CM has been little investigated, but it is important to consider the constraints of the game for its total comprehension (Ferreira, Volossovitch \& Sampaio, 2014). Initially, some sport-researchers based their studied about the psychological momentum by consulting basketball coaches (Burke, Aoyagi, Joyner \& Burke, 2003; Taylor \& Demick, 1994; Vallerand, Colavecchio \& Pelletier, 1988). The conclusions of these studies showed the CM as a theoretical concept which was not well defined and difficult to explain. Later Ferreira et al. (2014) and Navarro, Gómez, Lorenzo \& Jiménez (2013) identified the need for conceptual and methodological convergences over the CM. They continued with the analysis of the coach's standpoint, through the construction and validation of interviews to determine if practical knowledge of the game would help coaches to detect and confront the arrival of the CM in basketball.

The expert futsal coach, like the basketball coach, must face the criticality involved in his decisions. He needs to understand the influence exerted on a wide range of variables related to the game context, including the axis time-scoreboard, determinant for the arrival of CM. With limited data from qualitative studies, it was a useful exercise to extrapolate the results of some preliminary quantitative studies. Those revealed the significant influence of the score-line and remaining time on the variability of the offensive strategy of futsal teams, related to using the goalkeeper-as-an-outfield-player attack strategy (hereinafter 5vs4) to build an asymmetric competitive scenario, finding that it appears in the $100 \%$ of ball possessions analyzed with a score difference of 1 goal or more, but not in the case of a draw or favorable outcome (Barbosa, 2011). This strategy begins to be used in the final minutes of the match that getting lost (Ganef, Pereira, De Almeida \& Coppi, 2009; Ribeiro, 2011).

Although the research has not yet been able to determine the existence of the unfavorable $\mathrm{CM}$ in futsal and neither its possible relation with the coach's decision of using the 5vs4 strategy. However, the presence of this competitive scenario, brings greater efficiency compared to the 4vs4 symmetrical competitive scenario (Corrêa, Davids, Silva, Denardi \& Tani, 2014; Vicente-Vila, 2012; Vicente-Vila \& Lago-Peñas, 2016; Vieira, 2010). This greater effectiveness could be used as an early response of the coaches to face the arrival of a critical situation. 
Méndez-Dominguez, C.; Gómez-Ruano, M.A.; Ruiz-Pérez, L.M.; Cul, Y. (2017). Unfavorable critical moments and way of facing them from the futsal coach's point of view through ad hoc questionnaire. RICYDE. Revista internacional de ciencias del deporte, 50(13), 339-355. https://doi.org/10.5232/ricyde2017.05002

The futsal coaches experience will be valued to find out their knowledge about the CM, and their position related to the use and effectiveness of the goalkeeper as an outfiedl player procedure (5vs4) as a tactical-strategic plan to face the unfavorable CM. In addition, the coaches' opinions will be grouped in a questionnaire whose content is intended to be validated by calculating the $V$ Aiken coefficient (Aiken, 1980, 1985, Penfield \& Giaccobi, 2004), which has been shown to be appropriate to validate the content of programs and instruments related to the instruction and observation of behaviors in sports environments (García-Martín, Antúnez \& Ibáñez, 2016; García-Santos \& Ibáñez, 2016; González-Espinosa, Ibáñez, Molina, \& Galatti, 2017; Villarejo, Ortega, Gómez \& Palao, 2014).

The aims of the study were: 1 . Assess the coaches' experience in professional futsal matches over their knowledge about the unfavorable $\mathrm{CM}$ in futsal games; 2. Determine the relationship between $\mathrm{CM}$ and the decision and effectiveness of using the goalkeeper as an outfield player attack (5vs4) within the coach's tactical-strategic plan. 3. Validate the content of the coaches' opinion questionnaire so that it can be replicated in future investigations.

\section{Method}

\section{Participants}

In the present study, 129 coaches or assistant coaches working with teams of the 1st and 2 nd division of the National Futsal League of Spain (LNFS), and the 2nd B division of the National Committee of Spanish Futsal (CNFS) participated and completed the questionnaire, according to the following criteria: $1^{\circ}$ ) Having coached professional teams and players of a level equivalent to the 1st and 2nd LNFS division or coached in a semi-professional level, equivalent to CNFS 2nd B; $2^{\circ}$ ) Coaches who were active in the 2015-2016 season in a professional or semi-professional level (table 1).

Table 1. Personal and professional profile of the coaches participating in the questionnaire.

\begin{tabular}{|c|c|c|c|c|c|c|}
\hline \multicolumn{7}{|c|}{ COACH FUTSAL PROFILE } \\
\hline \multicolumn{7}{|c|}{ MIDDLE AGE: $38.5 \pm$} \\
\hline \multicolumn{7}{|c|}{ ACADEMIC LEVEL } \\
\hline GRADE & & & & $\mathrm{N}^{\mathrm{o}}$ & & $\%$ \\
\hline $\mathrm{Ph} D$ & & & & 1 & & \\
\hline Bachelor's degree & & & & 48 & & 37,20 \\
\hline University graduate & & & & 28 & & 21,70 \\
\hline Middle grade & & & & 52 & & 40,31 \\
\hline \multicolumn{7}{|c|}{ PROFESSIONAL DEGREE } \\
\hline COACH LICENSE & & & & $\mathrm{N}^{\mathrm{o}}$ & & $\%$ \\
\hline Level III & & & & 79 & & 61,24 \\
\hline Level II & & & & 40 & & 31 \\
\hline Level I & & & & 10 & & 7,75 \\
\hline \multicolumn{7}{|c|}{ CAREER AND MERITS } \\
\hline PARTICIPATION & & & & ITLES & & \\
\hline COMPETITION & EDICIONS & UEFA & $L E A G U E$ & CUP & $K I N G^{\prime} C U P$ & SUPERC \\
\hline UEFA & 27 & 11 & & & & \\
\hline $1^{a}$ División & 247 & & 31 & 22 & 19 & 17 \\
\hline $2^{\mathrm{a}}$ División & 196 & & 60 & & & \\
\hline $2^{\mathrm{a}} \mathrm{B}$ & 566 & & & & & \\
\hline TOTALS & 1036 & 11 & 91 & 22 & 19 & 17 \\
\hline
\end{tabular}


Méndez-Dominguez, C.; Gómez-Ruano, M.A.; Ruiz-Pérez, L.M.; Cul, Y. (2017). Unfavorable critical moments and way of facing them from the futsal coach's point of view through ad hoc questionnaire. RICYDE. Revista internacional de ciencias del deporte, 50(13), 339-355. https://doi.org/10.5232/ricyde2017.05002

\section{Questionnaire design and guidelines}

The coaches' knowledge about the CM and the way they solve the situation by using the tactical procedure of the 5vs4 strategy, were evaluated through an ad hoc questionnaire. It was configured through a mixed process, following the introductory fundaments and research objectives, and through experts' judgments (Rodríguez, Gil \& García, 1996).

The coaches responded to the greater or lesser influence of 20 items that were finally selected, and whose complete redaction appears in the results tables (tables 5 y 6). For these 20 items a pattern with a nonlinear sequential order of the different domains of criticality in futsal was established. In the final model of the questionnaire the items are grouped in a three-dimensional construct, which were acquiring meaning through a set of coherent questions related to the purpose of the research, where the contents and sequence were connected to reflect a homogeneous topic (Cerdá, 1991).

(i) the dimension about the unfavorable $\mathrm{CM}$ in futsal included nine questions related to determinants of criticality (score-line, remaining time and accumulative fouls) attempting to assess the critical potential of these variables in an individual or interactive way. Regarding the score-line, the limit of goal difference that characterizes balanced games was also included in the questionnaire (see table 2).

Table 2. Variables related to the unfavorable CM dimension in futsal and corresponding items within the questionnaire.

1. Level of criticalness of the match status variable in the 1st half with differences a 2-3 goals difference, and importance of the scoreboard magnitude to recognize the limit that characterizes balanced matches in 1 st half.

4. Level of criticalness of the match status variable in the 2 nd half with a difference up to 2 goals, and importance of the scoreboard magnitude to recognize the limit that characterizes balanced matches.

7. Level of criticalness of the remaining time variable in the last $5 \mathrm{~min}$ of the 1 st half and its importance as a conditioning factor of the game and of the strategy.

10. Level of criticalness of the remaining time variable in the last 8-10 min of the 2 nd half and its importance as conditioning factor of the game and the strategy.

13. The precursor variables Match Status and remaining time of the unfavorable CM of a team in a competition which registers a disadvantage of 2-3 goals and within the final 8-10 minutes.

16. The precursor variables Match Status and remaining time of the unfavorable CM of a team in a competition that registers a disadvantage of 1-2 goals and within the last 5 minutes.

12. Accumulative foul as a precipitating variable of the unfavorable CM.

18. Interactive effects of the variables Match Status, remaining time and Fouls as triggers of the unfavorable CM.

20. Partial performances obtained in unfavorable CMs as indicators of the probability of success in balance competitions.

(ii) The implication of the 5vs4 strategy coinciding with the unfavorable CM placed the coaches in different scenarios when attacking with 5vs4 or when defending that attack, in order to measure their perception about the hypothetical stress level of their teams when they must face them. Also other two scenarios that surveyed if the magnitude that reaches the time - score-line axis would help them to recognize an unfavorable $\mathrm{CM}$, and if that encourages the attack with the 5vs4 strategy (see table 3). 
Méndez-Dominguez, C.; Gómez-Ruano, M.A.; Ruiz-Pérez, L.M.; Cul, Y. (2017). Unfavorable critical moments and way of facing them from the futsal coach's point of view through ad hoc questionnaire. RICYDE. Revista internacional de ciencias del deporte, 50(13), 339-355. https://doi.org/10.5232/ricyde2017.05002

Table 3. Variables related to the use of the goalkeeper as an outfield player coincident with the unfavorable CM in futsal and corresponding items within the questionnaire.

2. Stress level perception at the time of using the attack with the goalkeeper as an outfield player with a 1-2 deficit goals and 5 minutes to finish the competition.

5. Stress level perception at the time of defending the attack with the goalkeeper as an outfield player with a tied score and 5 minutes to finish the competition.

8. Stress level perception at the time of defending the attack with the goalkeeper as an outfield player with 1-2 deficit goals and 5 minutes to finish the competition.

14. Consideration of the unfavorable CM with the team in disadvantage of 2-3 goals in the last 8-10 minutes and the possibility to face it by attacking with the goalkeeper as an outfield player.

17. Consideration of unfavorable CM with the team in disadvantage of 1-2 goals in the last 5 minutes and the possibility to face it by attacking with the goalkeeper as an outfield player.

And (iii) in the dimension about efficacy of the attack or defense of the 5vs4 strategy, six questions were formulated to know the degree of effectiveness that coaches give when assessing the effects of certain situations when attacking with 5vs4 and when defending it. Additional information was included to clarify the key concepts of each domain at the foot of the page to ensure a correct understanding by the coaches (see table 4).

Table 4. Variables related to the effectiveness of the goalkeeper as an outfield player in an offensive and defensive situation and corresponding items within the questionnaire.

3. Tactical effectiveness of attacking with the goalkeeper as an outfield player with shooting action in any zone between 6 and 10 meters.

6. Tactical effectiveness of attacking with the goalkeeper as an outfield player with shooting action in the 6 meters area zone.

9. Tactical effectiveness of defending against the attack with the goalkeeper as an outfield player with an error action in the opponent pass.

11. Tactical effectiveness of defending against the attack with the goalkeeper as an outfield player with ball recovery action by direct defensive action.

15. Tactical effectiveness of attacking with the goalkeeper as an outfield player determined by the positive relationship between the number of plays and the number of shoots made.

19. Tactical effectiveness of attacking or defending with the goalkeeper as an outfield in unfavorable CM as an indicator of the team competence level.

\section{Procedure}

The clubs gave the permission to contact their coaches to give them information about the study, the questions and their different areas, and the procedure to answer them. After obtaining their consent to participate, the electronical questionnaire was sent to them. To collect the coaches' opinions, the final document was created through the Google Docs forms, which facilitates the creation, editing and registration of the questions and allows for the storage of coaches' answers in Excel spreadsheets. The answers to each question were chosen by the coaches on a Likert scale of 5 levels from lowest to highest impact $(1=$ none, $2=$ little, $3=$ medium, $4=$ quite, $5=$ maximum). The sending of questionnaires began with the season started in September 2015 and its reception was extended until December 2015. 
Méndez-Dominguez, C.; Gómez-Ruano, M.A.; Ruiz-Pérez, L.M.; Cul, Y. (2017). Unfavorable critical moments and way of facing them from the futsal coach's point of view through ad hoc questionnaire. RICYDE. Revista internacional de ciencias del deporte, 50(13), 339-355. https://doi.org/10.5232/ricyde2017.05002

\section{Validity and trustworthiness}

To validate the content of the questionnaire we focus on the adequacy or representativeness section of the items, through 2 well differentiated phases. A first phase where only 3 futsal experts participated, who were in charge of selecting the most appropriate items and depurated them for their final draft. Also, another phase in which the relevance of the selected items is put to judgment to see if they are adequate to define the domain of criticality according to the sample of coaches selected.

The initial phase of the questionnaire was guided in three different stages: (i) a preliminary version of the questionnaire was designed with the support of available scientific research. The total of the initial sample resulted in 78 items, which corresponded to closed questions, and their response should receive a value assigned on a Likert scale ranging from 1 (less appropriate) to 5 (more appropriate) while other open questions tried to facilitate a greater depth of terms and concepts and enable new routes or tracks offered by experts; (ii) Each of the 78 items was viewed and evaluated by 3 independent experts of futsal. They were considered experts because they obtained the greatest achievement or recognition in this sport such as first place in a FIFA World Championship or European Championship. After deciding which experts fulfilled the requirement, the necessary information was transferred for their collaboration. Of all 78 initial items, 20 items that reached a value of $80 \%$ according to the judges on the scoring scale, were incorporated into the final questionnaire (EscobarPérez \& Cuervo-Martínez, 2008); iii) In order to obtain the necessary semantic validation that facilitated the understanding of terms, words and meanings (Rodríguez et al, 1996), those 20 items were passed to the experts to carry out relevant reformulations or modifications of the initial version.

The second phase evaluated the relevance of the items selected in that first phase, which was a duty of the total of coaches' sample. For this purpose, a logical validity method was applied based on the opinion of expert coaches using the Aiken $V$ coefficient (Aiken, 1980, 1985), that tried to quantify the content validity or relevance of each of the items respect to the content domain in $n=129$ judges, whose magnitude was from 0.00 to 1.00 ; being the value 1.00 the greatest possible magnitude that indicated a perfect agreement among the judges regarding the highest validity score (5) of the contents evaluated in the scale. A computer application developed by Merino and Livia (2009) was used to calculate the confidence intervals using the score method (Penfield \& Giacobbi, 2004) at the levels of 90\%, 95\% and $99 \%$. In order to calculate the exact critical value of the Aiken $V$, the formula proposed by Aiken (1985) for large samples was used, taking into account the number of judges and items in the questionnaire sample. This value indicates which items are valid depending on whether their value exceeds the critical value of Aiken's $V$, where $z$ is the level of significance, $m$ the number of items that the experts should valuate, $n$ is the number of expert judges that participate in the study and $c$ the maximum value that can valuate an item.

$$
\bar{V}=.5+\left(z .2 \sqrt{\frac{3 m n(c-1)}{c+1}}\right)
$$

In the tables results (tables 5 y 6 ) the values obtained in the Aiken $V$ and the $95 \%$ confidence intervals for the different items related to criticality are shown. The exact critical value of the Aiken $V$ to test the null hypothesis where $V_{0}=0.5$ with the formula for large samples was 
Méndez-Dominguez, C.; Gómez-Ruano, M.A.; Ruiz-Pérez, L.M.; Cul, Y. (2017). Unfavorable critical moments and way of facing them from the futsal coach's point of view through ad hoc questionnaire. RICYDE. Revista internacional de ciencias del deporte, 50(13), 339-355. https://doi.org/10.5232/ricyde2017.05002

0.70 , according to the final judges' sample, which because of it being larger, requires a lower concordance. The results showed that the coaches agreed on 19 of the 20 items to reach $V$ coefficients of 0.90 or above, at a statistical significance level of $p<0.05$, with a confidence interval $\mathrm{p}=0.95$, where only one Item reached a lower relative value of 0.74 , which might suggest its modification, however it was decided to keep it that way because, in addition of being relevant, it represented the theoretical construct of the study.

Crombach's $\alpha$ was used to measure the internal consistency of the questionnaire. The results show a high reliability of the questionnaire, which reached a value of .82 . Therefore, we can mention that the design of the questionnaire with the collected items is satisfactory according to criterion 0.70 from Field (2009). In addition, we included the test-retest reliability of the responses provided by the coaches were tested by the temporary stability of the measures. So that $10 \%$ of the sample $(n=13)$, randomly selected, was asked to complete the questionnaire two months later from the first data collection. In order to examine the correspondence between the responses given by the coaches at both moments, the nominal agreement percentage was calculated (Cubo, Martín \& Ramos, 2011). This index allows to calculate the agreement percentage between two observers (observations) through the proportion of agreements $(\mathrm{Po})$, which is found with the quotient between the number of agreements and the number of observations or items. The intra-observer reliability obtained values between 0.75 and 1 between the information given by the coaches in both moments, which shows a very high agreement between the observations and confirms that the data is reliable.

\section{Results}

The calculation of the mean $(\overline{\mathrm{x}})$, standard deviation (SD) and Aiken's $V$ coefficient $(V)$ for each item is shown in Tables 5 and 6.

\section{Defining Critical Moment}

The coaches gave a high score to the fact that an unfavorable score of 2-3 goals in the 1st half, is the maximum limit to have options of "still surviving in the match", it could mean that a team reaches its highest level of criticality, and what this could represent to the effects of competitive stress at that time. The importance of the score-line magnitude in the 2 nd half of the game is representative of its highest critical potential, therefore there was a greater agreement among the coaches to recognize that the limit of up 2 goals difference belongs to a balanced game (Ítem $4: \overline{\mathrm{X}}=3.79, V=0.95$ ).

Regarding the variable remaining time, the futsal coaches were mostly in agreement on including the last $5 \mathrm{~min}$ of the game as maximum exponents of the critical level, and especially those minutes on the 2 nd half even extending that critical level to the last 8-10 min of the match. (Ítem 10: $\overline{\mathrm{x}}=3.59, V=0.90$ ).

The questionnaire showed the importance that the axis remaining time-scoreboard in line had for coaches in terms of the critical level. High values of criticality was given to the situations of competition where a team is at a disadvantage of losing 2-3 goals in the end of the match (8-10 min) (Ítem 13: $\overline{\mathrm{x}}=4.18, V=0.99)$, or where a team is losing 1-2 goals within the last 5 min (Ítem 16: $\bar{x}=4.38, V=0.99$ ). Therefore, the critical potential of the score-line and the remaining time is significant for futsal coaches as powerful driver of the unfavorable $\mathrm{CM}$ in undecided matches. 
Méndez-Dominguez, C.; Gómez-Ruano, M.A.; Ruiz-Pérez, L.M.; Cul, Y. (2017). Unfavorable critical moments and way of facing them from the futsal coach's point of view through ad hoc questionnaire. RICYDE. Revista internacional de ciencias del deporte, 50(13), 339-355. https://doi.org/10.5232/ricyde2017.05002

Table 5. Descriptive results for each item (mean $(\overline{\mathrm{X}})$ and standard deviation (SD)), Aiken's V coefficient $(\mathrm{V})^{\text {a }}$.

\begin{tabular}{|c|c|c|c|c|c|}
\hline \multirow{3}{*}{ ÍTEMS Likert scale 1-5: $1=$ none;2= little; $3=$ medium; $4=$ quite $; 5=$ maximum } & \multicolumn{5}{|c|}{ Adecuacy } \\
\hline & \multirow[b]{2}{*}{$\overline{\mathbf{x}}$} & \multirow[b]{2}{*}{ SD } & \multirow[b]{2}{*}{$V$} & \multicolumn{2}{|c|}{$95 \% \quad I C$} \\
\hline & & & & $I$ & $S$ \\
\hline $\begin{array}{l}\text { 1. The score-line and remaining time variables can generate disturbance in the attack } \\
\text { /defense behavior of your players. Do you consider that a difference of } 2 \text { to } 3 \text { goals } \\
\text { (important) during the } 1 \text { st half is the limit with which the maximum value of criticality } \\
\text { is reached in the scoreboard of the disadvantaged team, from which a balanced game } \\
\text { becomes an unbalanced one? }\end{array}$ & 3.63 & 1.05 & .91 & .85 & .95 \\
\hline $\begin{array}{l}\text { 2. My team is ready to use the attack with the goalkeeper as an outfield player in a } \\
\text { situation where the score-line is shortly handicapped ( } 1 \text { or } 2 \text { goals) and there is little } \\
\text { time to the end of the game (within the range of the last } 5 \text { minutes). What level of } \\
\text { competitive stress can it be? }\end{array}$ & 4.09 & .81 & .99 & .98 & 1 \\
\hline $\begin{array}{l}\text { 3. My team has made the attack with the goalkeeper as an outfield player with a final } \\
\text { action of an uninterrupted shoot done in the opponent court in any zone between } 6 \text { and } \\
10 \mathrm{~m} \text { of the goal. Determines the degree of tactical efficiency obtained. }\end{array}$ & 3.55 & .87 & .89 & .82 & .93 \\
\hline $\begin{array}{l}\text { 4. The score-line and remaining time variables can generate disturbance in the attack / } \\
\text { defense behavior of your players. Do you consider that a difference of up } 2 \text { goals } \\
\text { (recoverable) during the } 2 \text { nd half is the limit with which the maximum value of } \\
\text { criticality is reached in the scoreboard of the disadvantaged team, from which you } \\
\text { move from which a balanced game becomes an unbalanced one? }\end{array}$ & 3.79 & 1.12 & .95 & .91 & .97 \\
\hline $\begin{array}{l}\text { 5. My team is ready to defend the attack with the goalkeeper as an outfield player in a } \\
\text { situation where the scoreboard is draw and there is little time to the end of the game } \\
\text { (within the range of the last } 5 \text { minutes). What level of competitive stress can it be? }\end{array}$ & 3.79 & 1.08 & .95 & .91 & .97 \\
\hline $\begin{array}{l}\text { 6. My team has made the attack with the goalkeeper as an outfield player with a final } \\
\text { action of an uninterrupted shoot done in the opponent court in the penalty area. } \\
\text { Determines the degree of tactical efficiency obtained. }\end{array}$ & 4.32 & .74 & .98 & .97 & .99 \\
\hline $\begin{array}{l}\text { 7. The remaining time variable can generate disturbance in the behavior attack / defense } \\
\text { of your team. Do you consider that the arrival of the last } 5 \text { minutes interval in the } 1 \text { st } \\
\text { half, can reflect that the Critical Level of the variable remaining time reaches a } \\
\text { maximum value, conditioning the coach's decisions in relation to the score-line? }\end{array}$ & 2.58 & 1.05 & .74 & .66 & .81 \\
\hline $\begin{array}{l}\text { 8. My team is ready to defend the attack with the goalkeeper as an outfield player in a } \\
\text { situation where the scoreboard is in disadvantage ( } 1 \text { or } 2 \text { goals) and there is little time to } \\
\text { the end of the game (within the last } 5 \text { minutes interval). What level of competitive stress } \\
\text { can it be? }\end{array}$ & 3.96 & .86 & .99 & .98 & 1 \\
\hline $\begin{array}{l}\text { 9. My team has defended the attack with the goalkeeper as an outfield player getting the } \\
\text { ball out of the court after an error in the pass by defensive deterrent action. Determines } \\
\text { the degree of tactical efficiency obtained by your team in defense. }\end{array}$ & 3.79 & .88 & .95 & .91 & .97 \\
\hline $\begin{array}{l}\text { 10. The remaining time variable can generate disturbance in the behavior attack / } \\
\text { defense of your team. Do you consider that the arrival of the last } 8-10 \text { minutes interval } \\
\text { in the } 2 \text { nd half, can reflect that the Critical Level of the variable remaining time reaches } \\
\text { a maximum value, conditioning the coach's decisions in relation to the score-line? }\end{array}$ & 3.59 & .98 & .90 & .84 & .94 \\
\hline
\end{tabular}

'Notes': a The critical $V$ value to test the null hypothesis where $\mathrm{Vp}=0.5$ as Aiken (1985) points out with the formula for large samples is .70 under a 0.05 Type I error.

b maximum critical level. Each contextual variable (score-line, remaining time and accumulative fouls) is graded on a Likert scale of 1 to 5 from lowest to highest to determine the critical level, which reflects the state of "stress" a team has in relation to the match. The value of the variable remaining time is increasing for both teams until reaching its maximum as it gets to the final intervals. The value of the fouls acquires its maximum with the 5th foul committed. Regarding the scoreboard, both teams start from an average value of (3) that reflects the initial balance. But as the goal difference changes, the team that makes a goal descends to its critical level (2) and the team that receive it increases to (4) getting the maximum value of (5), if conceiving a new goal, which puts the difference in 2 goals or more.

The signaling of the 5th accumulative foul reached a very high score among the coaches as a precipitating event to the arrival of an unfavorable CM, especially in tied games, where a new accumulative foul gives the opponent an advantage in the game that allows them to kick a 10 $\mathrm{m}$ penalty shoot without human wall in front of the goalkeeper (Ítem $12: \overline{\mathrm{X}}=4.31, V=0.99$ ). 
Méndez-Dominguez, C.; Gómez-Ruano, M.A.; Ruiz-Pérez, L.M.; Cul, Y. (2017). Unfavorable critical moments and way of facing them from the futsal coach's point of view through ad hoc questionnaire. RICYDE. Revista internacional de ciencias del deporte, 50(13), 339-355. https://doi.org/10.5232/ricyde2017.05002

Table 6. Descriptive results for each item (mean $(\overline{\mathrm{x}})$ and standard deviation (SD)), Aiken's V coefficient $(\mathrm{V})^{\mathrm{a}}$.

\begin{tabular}{|c|c|c|c|c|c|}
\hline \multirow{3}{*}{ ÍTEMS Likert scale 1-5: $1=$ none; $2=$ little; $3=$ medium; $4=$ quite $; 5=$ maximum } & \multicolumn{5}{|c|}{ Adecuacy } \\
\hline & \multirow[b]{2}{*}{$\overline{\mathbf{x}}$} & \multirow[b]{2}{*}{ DT } & \multirow[b]{2}{*}{$\boldsymbol{V}$} & \multicolumn{2}{|c|}{$95 \% I C$} \\
\hline & & & & $\boldsymbol{I}$ & $S$ \\
\hline $\begin{array}{l}\text { 11. My team has defended the attack with the goalkeeper as an outfield player (5vs4) } \\
\text { strategy recovering the ball by a direct defensive action in anticipation, interception or } \\
\text { theft. Determines the degree of defensive tactical efficiency obtained by your team. }\end{array}$ & 4.79 & .47 & .99 & .98 & 1 \\
\hline $\begin{array}{l}\text { 12. Regarding the accumulated fouls variable, do you think that the signal of the } 5 \text { th } \\
\text { accumulative team foul in a balanced match can be a precipitating event of the arrival } \\
\text { of an unfavorable critical moment? }\end{array}$ & 4.31 & .69 & .99 & .98 & 1 \\
\hline $\begin{array}{l}\text { 13. Determine the critical level of your team in a hypothetical competitive situation } \\
\text { where you are at an important disadvantage (difference between } 2 \text { and } 3 \text { goals) and the } \\
\text { end of the match is close (within the last } 8-10 \text { minutes interval). }\end{array}$ & 4.18 & .80 & .99 & .98 & 1 \\
\hline $\begin{array}{l}\text { 14. If from the above situation you think your team is in an unfavorable critical } \\
\text { moment, in what degree do you usually face it using the goalkeeper as an outfield } \\
\text { player (5vs4) strategy? }\end{array}$ & 3.96 & .90 & .98 & .96 & .99 \\
\hline $\begin{array}{l}\text { 15. Do you consider that the number of non-intervened shoots at goal is important to } \\
\text { determine that your team has been effective in the attack with the goalkeeper as an } \\
\text { outfield player ( } 5 \mathrm{vs} 4 \text { ) strategy? }\end{array}$ & 4.09 & .84 & .98 & .97 & .99 \\
\hline $\begin{array}{l}\text { 16. Determine the critical level of your team in a hypothetical match situation where } \\
\text { you are in little disadvantage situation (difference of } 1 \text { or } 2 \text { goals) and there is little time } \\
\text { to the end (within the last } 5 \text { minutes interval). }\end{array}$ & 4.38 & .71 & .99 & .98 & 1 \\
\hline $\begin{array}{l}\text { 17. If from the above situation you think your team is in an unfavorable critical } \\
\text { moment, to what extent do you usually face it using the tactical procedure of the } \\
\text { goalkeeper as an outfield player }(5 \mathrm{vs} 4) \text { strategy? }\end{array}$ & 4.44 & .77 & .99 & .98 & 1 \\
\hline $\begin{array}{l}\text { 18. Do you think that interactive effects of the variables score line, remaining time and } \\
\text { accumulated fouls, may end up setting unfavorable critical moments }{ }^{b} \text {, whose effects in } \\
\text { the team play strategy have great significance on the outcome of the game? }\end{array}$ & 4.61 & .65 & .99 & .98 & 1 \\
\hline $\begin{array}{l}\text { 19. As an expert coach, to what extent do you think your team is effective }{ }^{\mathbf{c}} \text { attacking } \\
\text { with the goalkeeper as an outfield player strategy or defending it in the critical moments } \\
\text { of the game, can it be an indicator of their competition level in attack or defense to } \\
\text { resist the stress of competition.? }\end{array}$ & 4.27 & .69 & .99 & .98 & 1 \\
\hline $\begin{array}{l}\text { 20. As an expert coach, to what extent do you consider that the number of positive and } \\
\text { negative partials }{ }^{d} \text { obtained by both teams in the critical moments of the game, and } \\
\text { when maintaining the trend of a balanced game, can it be a good indicator of the } \\
\text { probability of success in the outcome of the game? }\end{array}$ & 4.17 & .70 & .99 & .98 & 1 \\
\hline
\end{tabular}
samples is .70 under a 0.05 Type I error.

b critical moments: The scoreboard, time play and number of fouls throughout the match variation dynamic is weighted on a scale with a graduation from 1 (lowest critical value) to 5 (highest critical value). The sum of the values obtained by these 3 variables can reach the critical threshold establish and cause a team to develop its critical attack-defense cycle.

c effectiveness: We consider that a team has been effective in attack using the goalkeeper as an outfield player if it has finished the action with an uninterrupted shoot by the opponent. While it would be effective in defense without having received a shoot or managed to neutralize it.

d positive and negative partials: This variable reflects the sum of the effectiveness values obtained in each attack-defense cycle, resulting in a positive, negative or neutral value during the game. The game tendency establishes for the attack a positive value when shooting, and a negative value if there is no shoot; In defense a positive value would be stopping the shoot of the opponent, and a negative value to have granted shoot. So, the sum attack and defense of the unit allows us to obtain a partial performance.

The coaches' answers about the critical level reached by the variables score-line, remaining time and fouls, showed the highest level of agreement about the interactive effects of those variables, that could be the trigger of unfavorable CMs, which on the teams' performance would have a great significance effect on the final match outcome for futsal teams (Ítem 18: $\overline{\mathrm{X}}=4.61, V=1)$. Figure 1 shows that in futsal, the unfavorable $\mathrm{CM}$ is a concept that could be bounded in time and form by coaches under a highly defined graphic scheme. 
Méndez-Dominguez, C.; Gómez-Ruano, M.A.; Ruiz-Pérez, L.M.; Cul, Y. (2017). Unfavorable critical moments and way of facing them from the futsal coach's point of view through ad hoc questionnaire. RICYDE. Revista internacional de ciencias del deporte, 50(13), 339-355. https://doi.org/10.5232/ricyde2017.05002

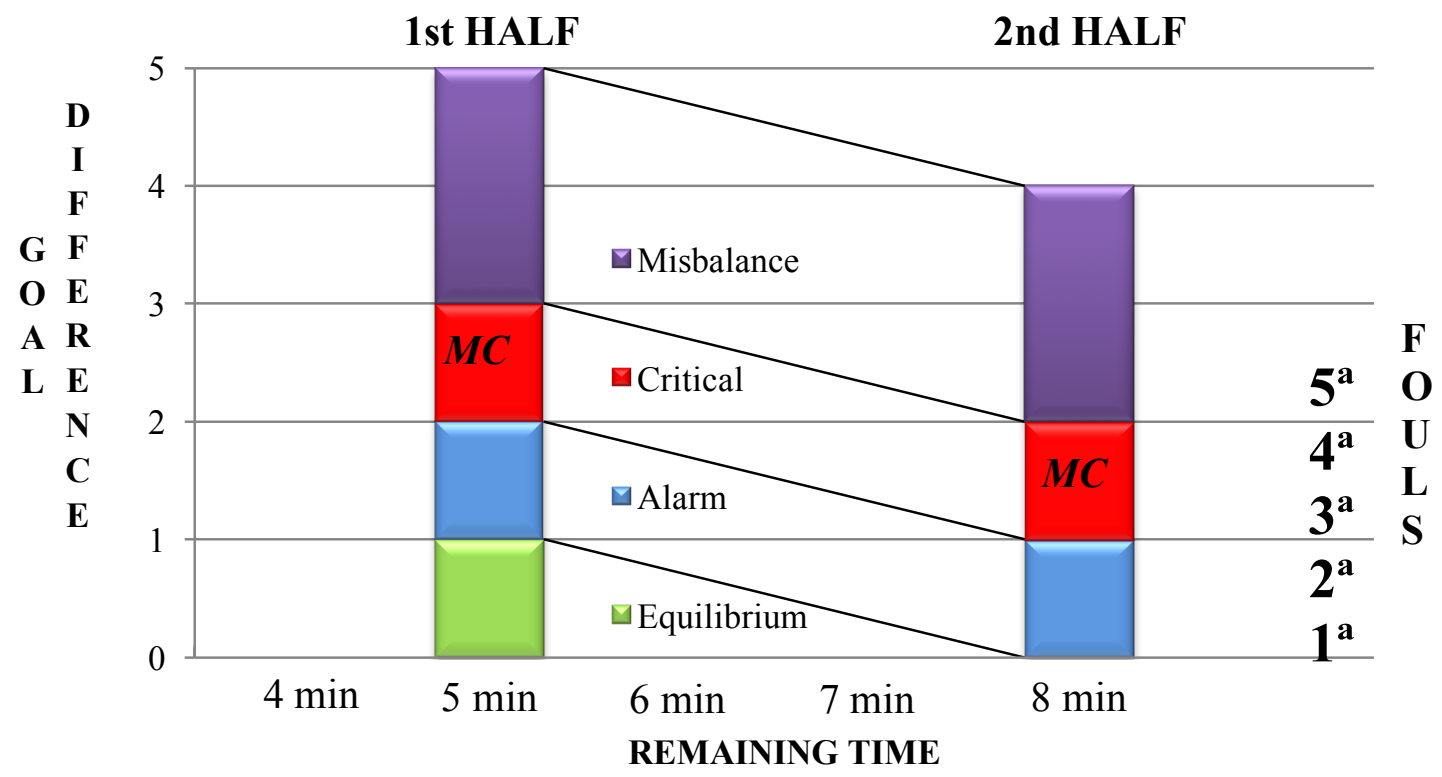

Figure 1. Conceptual scheme of unfavorable critical moment in futsal.

Use of the 5vs4 is coincident with the unfavorable CM in futsal.

Most of the futsal coaches perceived that a tie game or a 1-2 goals disadvantage on the scoreboard and 5 min until the end of the match, could mean their teams to developed their $5 \mathrm{vs} 4$ strategy behaviors, both in attacking and defending, with high levels of stress (Items 2 , 5 and 8$)$.

The results showed that coaches could not remain impassive when facing an adverse scoreboard and getting closer to the end of the match, making them look for new patterns that could improve the collective effectiveness in offensive plays. In fact, nothing seemed to have more importance than the proximity of a defeat to recognize that their teams were in the most unfavorable CM. So that they chose to attack with the 5vs4 strategy, attempting to break and change the negative game situation (Item 14: $\bar{x}=3.96, V=0.98$; Item 17: $\bar{x}=4.44, V=0.99$ ).

Futsal experts agreed that the importance of shooting on goal when attacking using the 5vs4 strategy or recovering the ball when defending to it, has an additional value when the team was in an unfavorable CM. It is during these moments that those actions become decisive for the outcome. Thus, the effectiveness achieved in the corresponding game phase was highly evaluated by the coaches as a good indicator of the competence level of their teams (Item 19: $\overline{\mathrm{x}}=4.27, V=0.99)$.

Figure 2 and Table 7 summarize in a graphical and schematic way the qualitative study of the effectiveness of the 5vs4 attack in CM. 
Méndez-Dominguez, C.; Gómez-Ruano, M.A.; Ruiz-Pérez, L.M.; Cul, Y. (2017). Unfavorable critical moments and way of facing them from the futsal coach's point of view through ad hoc questionnaire. RICYDE. Revista internacional de ciencias del deporte, 50(13), 339-355. https://doi.org/10.5232/ricyde2017.05002



Figure 2. Recreation of the attack with goalkeeper as an outfield player strategy based on the critical variables according to the expert futsal coaches' point of view.

Table 7. Summary of the critical factors related to the presence of the attack with goalkeeper as an outfield player according to the expert futsal coaches' point of view.

\begin{tabular}{ll}
\hline GOALKEEPER AS AN OUTFIELD FIELD PLAYER COINCIDENT WITH UNFAVORABLE CRITICAL MOMENT \\
\hline $\begin{array}{c}\text { location } \\
\text { nature of the game } \\
\text { CM intensity }\end{array}$ & In situations of tie in the scoreboard, but especially at a disadvantage 5 min of both periods, extendable until the last 8 min of the 2nd half \\
\hline precipitant factor & The appearance of the 5th foul \\
\hline Attack with goalkeeper as an outfield player coincides with a high criticality state, in \\
relation to the disadvantage in the scoreboard, little remaining time and the accumulated \\
fouls limit. \\
CM volume \\
$\begin{array}{l}\text { The number of critical units (low-medium-high) can determine the psychological impact } \\
\text { that is generated at the moment of playing with the goalkeeper as an outfield player. }\end{array}$ \\
$\begin{array}{l}\text { It evaluates the shoot on goal not intervened while not giving the opponents the opportunity } \\
\text { to attack. }\end{array}$
\end{tabular}

\section{Discussion}

The objectives of the study have led us to understand the theoretical and practical knowledge of the CM derived from the futsal coach thinking. Additionally, if the coach finally decides to face the CM by using the goalkeeper as an outfield player, so that this questionnaire was presented for the purpose of make it valid. The findings obtained from the futsal coaches' answers indicated their understanding and proceeding about the unfavorable CM. Firstly, futsal coaches considered that the player' behavior in attack and defense is affected by the dynamics of the score-line and the remaining time left to the end of the game. Those were the most powerful contextual referents to determine the critical level or state of criticality in their 
Méndez-Dominguez, C.; Gómez-Ruano, M.A.; Ruiz-Pérez, L.M.; Cul, Y. (2017). Unfavorable critical moments and way of facing them from the futsal coach's point of view through ad hoc questionnaire. RICYDE. Revista internacional de ciencias del deporte, 50(13), 339-355. https://doi.org/10.5232/ricyde2017.05002

teams, which can lead to the so-called unfavorable CM. Secondly, experts agreed almost $90 \%$ of the time in deciding to attack with the 5vs4 strategy when facing the futsal CM. These results agreed with the recent qualitative researches on CMs, where the basketball coach's speech confirmed that points difference, remaining time, and balance/imbalance perception are the most important situational variables which explain how expert coaches deal with critical situations of the game (Ferreira et al, 2014; Navarro et al., 2013).

The goals or points difference in the scoreboard is an objective mark and generally recognized by the coaches as a cut-off action that will characterize the equilibrium/imbalance relationship teams create (Ferreira et al, 2014). Without any previews background in futsal, the coaches perceive that a maximum of up 2 goals difference in the 2 nd half is the upper limit of a balanced match. It is likely that the coach deep inside thinks that in balanced matches a disadvantage of this type can be recovered, even though not is easy, not because of the level of the opponent, but due to factors such as physical or psychological fatigue of the players. When one of these balanced matches is reaching the end, professionals and researchers consent that it is the moment to take decisive actions which consequences would determine the winner of the game. The finals 8-10 min of the 2 nd half are the highest exponents of the critical level for futsal coaches, which is a fact prove in basketball literature, where the arrival of the last $5 \mathrm{~min}$ of a match becomes the temporary reference of the maximum level of criticality (Ferreira, Sampaio, Ibañez \& Volossovitch, 2004; Navarro, Lorenzo, Gómez, \& Sampaio, 2009).

The fact that the teams can reach the end of the game with a tied scoreboard or a slightly imbalance, turned out to be another important variable that can suppose an advantage in the game and in the scoreboard, that can break or tie even more the outcome of the match. The futsal coaches highly valued that the signal of the 5th accumulative team foul can be a precipitating event of the arrival of an unfavorable CM, especially in tied games. The available research in basketball also confirms that the arrival of a $\mathrm{CM}$ in the game is sometimes coincident with the 4th regulatory foul of a team (Ribeiro \& Sampaio, 2004; Sampaio, Lorenzo \& Ribeiro, 2006).

Both, the basketball experts surveyed in the study of Ferreira et al. (2014) and the futsal experts who were consulted in this study, agreed in pointing out the multifactorial and interactive reasons that determine the existence of a game CM. They consider a specific time interval of play, and its relation to the points or goals' difference, and the possible implication in the players' psychological states as the decisive factors. They emphasize in the importance of the team's 4th foul, in basketball, or 5th team foul in futsal, as a precipitating event of the arrival of an unfavorable CM.

The impact generated during the game by the psychological factor of the player can precipitate, maintain or dissipate the arrival of a $\mathrm{CM}$ according to basketball coaches (Navarro et al, 2013; Bar-Eli \& Tractinsky, 2000), which was measured in futsal via the socalled Critical Level (Table 8). The critical level tries to be an approximate value of the state of criticality in which a team can be found, being in its essence an estimation of competitive stress level or crisis to which the player or team may be submitted during the game, that can ultimately lead to the so-called unfavorable CM. Its measurement is a weighing of the dynamics variation that occurs within the goals difference in the scoreboard, remaining time and accumulated fouls, to the solution mode proposed by McCutcheon (1997). It was established that each variable was provided with a numerically critical value that oscillates in a gradual scale from minor (one) to major (five), depending on its evolution and importance throughout the match. The sum of the values of each variable would result in certain critical 
Méndez-Dominguez, C.; Gómez-Ruano, M.A.; Ruiz-Pérez, L.M.; Cul, Y. (2017). Unfavorable critical moments and way of facing them from the futsal coach's point of view through ad hoc questionnaire. RICYDE. Revista internacional de ciencias del deporte, 50(13), 339-355. https://doi.org/10.5232/ricyde2017.05002

level for each team, with the highest values are identified as the arrival of the unfavorable $\mathrm{CM}$ for one team or both teams, in case of a match with maximum equilibrium.

Table 8. Critical level of contextual variables, unfavorable CM trigger.

\begin{tabular}{|c|c|c|c|c|c|c|c|c|c|c|c|c|c|c|c|}
\hline \multicolumn{16}{|c|}{ CRITICAL LEVEL } \\
\hline \multicolumn{4}{|c|}{ MIN 15 2ond half } & \multicolumn{6}{|c|}{ REMAINING TIME: 5 MIN } & \multicolumn{6}{|c|}{ SCOREBOARD: $2-4$} \\
\hline FOULS & \multicolumn{4}{|c|}{ INTER } & & GOAL & 2 & GOAL & & \multicolumn{3}{|c|}{ POZO M } & \multicolumn{2}{|r|}{ FOULS } & 3 \\
\hline Critical Level & 1 & 2 & 3 & 4 & 5 & & NC & Critical Level & 1 & 2 & 3 & 4 & 5 & \multicolumn{2}{|c|}{ NC } \\
\hline GOAL DIF & +2 & +1 & 0 & -1 & -2 & & 5 & GOAL DIF & +2 & +1 & 0 & -1 & -2 & & 1 \\
\hline TIME & 20 & 16 & 12 & 8 & 5 & & 5 & TIME & 20 & 16 & 12 & 8 & 5 & & 5 \\
\hline FOULS & 1 & 2 & 3 & 4 & 5 & & 4 & FOULS & 1 & 2 & 3 & 4 & 5 & & 3 \\
\hline & & & & & & $\sum$ & & & & & & & & $\Sigma$ & 9 \\
\hline
\end{tabular}

Definitely the concept of CM can be characterized and localized by futsal coaches, but we agree with Ferreira et al. (2014) that it has not been investigated yet with the sufficient scientific rigor to establish a precise definition which the majority can agree with.

Expert basketball coaches understand the game criticality by constructing mental representations about the type of decisions they would make in real game situations, mostly focused on the improvement of the tactical-strategic defensive plan (Ferreira et al, 2014). This aspect has also been possible to verify in their futsal experts colleagues but by emphasizing on the offensive plan, when fancing different critical scenarios they make the decision to use the tactical procedure of attacking with 5vs4 strategy to face what they consider an unfavorable moment. Studying this issue underlies the idea that an unfavorable $\mathrm{CM}$ in the final section of the game, with obvious consequences for an imminent defeat for either team, is the most powerful inciter of using the attack 5vs4 strategy. Therefore, the use of the tactical procedure of the goalkeeper as an outfield player is the argument used by most of the futsal coaches to try to unbalance, in favor of their interests, the final attack-defense balance in those delicate moments, and it is a decision that seems not to be conditioned by the fact that they perceive a high level of stress in their players, when they have to face with this strategy what they consider an unfavorable CM. Barbosa (2011) and Ganef et al. (2009) confirmed the probability of a highly significant coincidence between both factors, when they pointed out that the use of the asymmetric competitive scenario of the $5 \mathrm{vs} 4$ strategy appears in the final minutes of those matches where the teams have an unfavorable scoreboard of 1 goal and use the 5vs4 strategy to tie the game, or have more than 1 goal difference and use it to shorten that difference. Concluding, that the coaches use this procedure as a last strategical resource during the match. All of this accentuates the important interaction of the behavioral and environmental components.

Futsal coaches highly value the possibility that their teams finish most attacks with a shoot, and their defenses without receiving one, but in situations where the attack 5vs4 strategy appears, the action of shooting or not shooting acquires a decisive importance for them. For the attacker could mean that an advantageous space, more or less close to the goal was generated, that could cause a goal or a goal opportunity which agrees with different studies that find better absolute and relative offensive effectiveness ratings compared to the symmetric competitive scenario of 4vs4 (Vieira, 2010; Vicente-Vila, 2012; Vicente-Vila \& Lago-Peñas, 2016). For the team who defends because it ends up modifying the defensive subsystem through a significant reduction of the space to protect and of the interception 
Méndez-Dominguez, C.; Gómez-Ruano, M.A.; Ruiz-Pérez, L.M.; Cul, Y. (2017). Unfavorable critical moments and way of facing them from the futsal coach's point of view through ad hoc questionnaire. RICYDE. Revista internacional de ciencias del deporte, 50(13), 339-355. https://doi.org/10.5232/ricyde2017.05002

distance between defender/attacker. Which is confirmed as an effective defensive strategy related to passing errors in the resolution of the attack with the 5vs4 strategy (Corrêa et al., 2014), that is usually accompanied by an offensive transition that ends up with a high probability of scoring in the goal that probably cannot be defended with specific goalkeeper, because the opponent dispensed with him in an offensive phase (Ferreira-da-Silva, 2011; Martín-Colorado, 2013).

Although the effectiveness revealed in each of the antagonistic phases of the 5vs4 strategy may have important consequences on the outcome of the match (Ganef et al., 2009), especially if it is balanced one, the coach's decision to use this procedure continues to be doubted from the researched literature. Barbosa (2011) does not find alterations in the outcome of the match in $66 \%$ of the occasions in which the competitive scenario of the $5 \mathrm{vs} 4$ strategy is used, and Álvarez, Puente, Manero and Manonelles (2004) conclude that the goals obtained with the presence of this competitive scenario is greater in teams that defend with numerical inferiority (4\%) than in those who use the theoretical advantage of having one more field player (2\%). However, the results of Vicente-Vila and Lago-Peñas's study (2016) show that the probability of scoring a goal is 3.6 times higher when the team attacks with the $5 \mathrm{vs} 4$ strategy. These results show uncertainty about the decision to use the procedure of the goalkeeper as an outfield player, and leave open the debate on the most appropriate time for greater profitability.

The last objective of this research focused on the validity of a questionnaire that could be used in future research about the criticality in team sports. For this reason, the basic recommendations that Dunn, Bouffard and Rogers (1999) establish for the creation of measurement instruments that seek to determine their content validity were followed. The large sample of experts participating in the 2 nd phase $(n=129)$ meets the requirements established in the literature in terms of the number of experts, when compared with previous papers presented (Garcia-Martín et al, 2016; García-Santos et al., 2016; González-Espinosa et al, 2017; Villarejo et al, 2014). All items exceeded the critical cut-off value set at 0.70 for Aiken $V$, obtaining $V$ values above 0.90 , higheer than those proposed by Penfield and Giaccobbi (2004). In the first phase of the questionnaire elaboration, the observations of the 3 main experts were decisive in facilitating the necessary reduction of the items and their reformulation, which made the data collection process more agile.

As for the limitations of the study, open questions were not included due to the difficulty in categorizing the responses. The fact that the highest consensus may not have been reached demonstrates that the knowledge from the obtained data cannot be the reflection of a deep understanding on the coaches. In addition, the present results should be verified with groups of futsal coaches of different levels of competition (amateur, youth futsal, and women) or with coaches of other team sports. The practical applications related to the study, result in coaches being able to use this information to establish training objectives in which players are exposed to competitive scenarios of different criticality, alternating the use of the goalkeeper as an outfield player as a tactical procedure.

In conclusion, current research confirms that unfavorable futsal $\mathrm{CM}$ is a concept that can be timed and shaped by coaches, who consider that the effects of a variation on the score-line, remaining time and fouls can cause a stress level in the players, triggering the unfavorable CM. It is a common practice to decide to deal with them using the attack 5vs4 strategy. The ad hoc questionnaire can be used to analyze the assessment of expert coaches in relation to criticality, as shown by the fact that their items reach high values in relation to content validity by calculating the Aiken $V$ coefficient. Although there is lack research that consolidates the concept of criticality in each sport, the significance that researchers and 
Méndez-Dominguez, C.; Gómez-Ruano, M.A.; Ruiz-Pérez, L.M.; Cul, Y. (2017). Unfavorable critical moments and way of facing them from the futsal coach's point of view through ad hoc questionnaire. RICYDE. Revista internacional de ciencias del deporte, 50(13), 339-355. https://doi.org/10.5232/ricyde2017.05002

experts attribute to this moment reaches a considerable value because it can reflect the competitive capacity of teams and players, and be decisive in the outcome of the game. Coaches can use this information to set goals for players and teams during coaching and matches to prepare for different competitive scenarios.

\section{Acknowledgement}

The present study was supported by the Ministry of Economy and competitiveness of Spain with the project "Estudio de los complejos de juego y los perfiles de rendimiento en bádminton de élite COMPLEXBAD" (DEP2015- 67231-R).

\section{References}

Abraham, A.; Collins D., \& Martindale, R. (2006). The coaching schematic: validation through expert coach consensus. Journal of Sports Science, 24(6), 549-564. https://doi.org/10.1080/02640410500189173

Aiken, L. (1980). Content validity and reliability of single items or questionnaires. Educational and Psychological Measurement, 40(4), 955-959. https://doi.org/10.1177/001316448004000419

Aiken, L. (1985). Three coefficients for analyzing the reliability and validity of ratings. Educational and Psychological Measurement, 45(1), 131-142. https://doi.org/10.1177/0013164485451012

Álvarez, J.; Puente, J.; Manero, J., \& Manonelles, P. (2004). Análisis de las acciones ofensivas que acaban en gol de la liga profesional de fútbol sala española. Red: Revista de Entrenamiento Deportivo, 18(4), 27-32.

Barbosa, A. (2011). Variação tática de goleiro linha não altera o resultado das partidas de futsal na taça são paulo 2009. Revista Brasileira de Futsal e Futebol, 3(8), 101107.

Bar-Eli, M., \& Tractinsky, N. (2000). Criticality of game situations and decision making in basketball: an application of performance crisis perspective. Psychology of Sport and Exercise, 1(1), 27-39.

https://doi.org/10.1016/S1469-0292(00)00005-4

Burke, K.; Aoyagi, M.; Joyner, A., \& Burke, M. (2003). Spectator's perceptions of positive momentum while attending ncaa men's and women's basketball regular season contests: Exploring the antecedents - consequences model. Athletic Insight: The Journal of Sport Pscyhology, 5(3), 10-18.

Carvalho, J., \& Araujo, D. (2013). Contributo para a unificação do estudo do desempenho desportivo físico: o modelo eco-físico. In A. Volossovitch \& A. Ferreira (Eds.), Fundamentos e Aplicações em Análise do Jogo (pp. 61-90). Lisbon: Edições $\mathrm{FMH}$.

Cerdá, H. (1991). Los elementos de la investigación: como reconocerlos, diseñarlos y construirlos. Santa Fé de Bogotá: Editorial El Buho.

Corrêa, U.; Davids, K.; Silva, S.; Denardi, R., \& Tani, G. (2014). The influence of a goalkeeper as an outfield player on defensive subsystems in futsal. Advances in Physical Education, 4(2), 84-92.

https://doi.org/10.4236/ape.2014.42012

Côté, J., \& Gilbert, W. (2009). An integrative definition of coaching effectiveness and expertise. International Journal of Sports Science and Coaching, 4(3), 307-323. https://doi.org/10.1260/174795409789623892

Crust, L., \& Nesti, M. (2006). A review of psychological momentum in sports: Why qualitative research is needed. Athletic Insight. The Journal of Sport Psychology, $8(1), 1-15$. 
Méndez-Dominguez, C.; Gómez-Ruano, M.A.; Ruiz-Pérez, L.M.; Cul, Y. (2017). Unfavorable critical moments and way of facing them from the futsal coach's point of view through ad hoc questionnaire. RICYDE. Revista internacional de ciencias del deporte, 50(13), 339-355. https://doi.org/10.5232/ricyde2017.05002

Cubo, S.; Martín, B., \& Ramos, J. (2011). Métodos de investigación y análisis de datos en ciencias sociales y de la salud: Pirámide.

Dunn, J.; Bouffard, M., \& Rogers, T. (1999). Assessing item content-relevance in sport psychology scale-construction research: Issues and recommendations. Measurement in Physical Education and Exercise Science, 3(1), 15-36. https://doi.org/10.1207/s15327841mpee0301_2

Escobar-Pérez, J. \& Cuervo-Martínez, A. (2008). Validez de contenido y juicio de expertos: una aproximación a su utilización. Avances en Medición, 6(1), 27-36.

Ferreira-da-Silva, D. (2011). Situações de superioridade numérica ofensiva no Futsal. Estudo de padrões de jogo com recurso à análise Sequêncial. (Dissertação de Mestrado), Faculdade de Ciências do Desporto e de Educação Física. Universidade do Porto.

Ferreira, A.; Sampaio, J.; Ibañez, S., \& Volossovitch, A. (2004). Basketball coaches perceptions of game-related statistics and critical moments of the games. Paper presented at the Proceedings of the 9th Annual Congress of European College of Sport Sicences, Clermont Ferrand.

Ferreira, A.; Volossovitch, A., \& Sampaio, J. (2014). Towards the game critical moments in basketball: a grounded theory approach. International Journal of Performance Analysis in Sport, 14(2), 428-442.

Field, A. (2009). Discovering statistics using SPSS. London: Sage publications.

Ganef, E.; Pereira, F.; De Almeida, E., \& Coppi, A. (2009). Influência do goleiro-linha no resultado do jogo de futsal. RBFF-Revista Brasileira de Futsal e Futebol, 1(3), 186-192.

García-Martín, A.; Antúnez, A., \& Ibáñez, S. (2016). Análisis del proceso formativo en jugadores expertos: validación de instrumento/Analysis of expert players' training process: validation of tools. Revista Internacional de Medicina y Ciencias de la Actividad Física y del Deporte, 16(61), 157-182. https://doi.org/10.15366/rimcafd2016.61.012

García-Santos, D., \& Ibáñez, S. (2016). Diseño y validación de un instrumento de observación para la valoración de un árbitro de baloncesto (IOVAB). SPORT TKRevista EuroAmericana de Ciencias del Deporte, 5(2), 15-26.

González-Espinosa, S.; Ibáñez, S.; Molina, S., \& Galatti, L. (2017). Programas de intervención para la enseñanza deportiva en el contexto escolar, PETB y PEAB: Estudio preliminar. Retos, 31(1), 107-113.

Leite N.; Coelho E., \& Sampaio, J. (2011). Assessing the importance given by basketball coaches to training contents. Journal of Human Kinetics, 30(1), 123-133. https://doi.org/10.2478/v10078-011-0080-3.

Martín-Colorado, J. (2013). Diferentes usos y concepciones de la superioridad 5x4. Futbol - Táctico. Revista Digital de Fútbol y Fútbol sala, 78(1), 8-12.

McCutcheon, L. (1997). Does the establishment of momentum lead to athletic improvement? Perceptual and Motor Skills, 85(1), 195-203.

https://doi.org/10.2466/pms.1997.85.1.195

Merino, C., y Livia, J. (2009). Intervalos de confianza asimétricos para el índice la validez de contenido: Un programa visual basic para la $V$ de Aiken. Anales de Psicologia, 25(1), 169-171.

Navarro, R.; Gómez, M.; Lorenzo, J., \& Jiménez, S. (2013). Qualitative analysis of critical moments in basketball. Revista de Psicología del Deporte, 22(1), 249-251. 
Méndez-Dominguez, C.; Gómez-Ruano, M.A.; Ruiz-Pérez, L.M.; Cul, Y. (2017). Unfavorable critical moments and way of facing them from the futsal coach's point of view through ad hoc questionnaire. RICYDE. Revista internacional de ciencias del deporte, 50(13), 339-355. https://doi.org/10.5232/ricyde2017.05002

Navarro, R.; Lorenzo, A.; Gómez, M., \& Sampaio, J. (2009). Analysis of critical moments in the league ACB 2007-08. Revista de Psicología del Deporte, 18(3), 391395.

Penfield, R., \& Giacobbi, P. (2004). Applying a score confidence interval to Aiken's item content-relevance index. Measurement in Physical Education and Exercise Science, $8(4), 213-225$.

https://doi.org/10.1207/s15327841mpee0804_3

Ribeiro, C., \& Sampaio, J. (2004). Análise dos coeficientes de eficácia colectiva e dos acontecimentos precedentes aos momentos críticos dos jogos de basquetebol. Revista Portuguesa de Ciências do Desporto, 4(2 (suplemento)), 199-200.

Ribeiro, N. (2011). A influência do goleiro linha no resultado do jogo de futsal. RBFFRevista Brasileira de Futsal e Futebol, 3(9), 187-198.

Rodríguez, G.; Gil, J., \& García, E. (1996). Metodología de la investigación cualitativa (Aljibe Ed.). Malaga: Aljibe.

Sampaio, J.; Lorenzo, A., \& Ribeiro, C. (2006). Momentos críticos en los partidos de baloncesto: metodología para identificación y análisis de los acontecimientos precedentes. Cultura, Ciencia y Deporte: Revista de Ciencias de la Actividad física y del Deporte, 2(5), 83-88.

Serrano, J.; Shahidian, S.; Sampaio, J., \& Leite, N. (2013). The Importance of Sports Performance Factors and Training Contents from the Perspective of Futsal Coaches. Journal of Human Kinetics, 38(1), 151-160. https://doi.org/10.2478/hukin-2013-0055.

Smith, M., \& Cushion, C. (2006). An investigation of the in-game behaviours of professional, top-level youth soccer coaches. Journal of Sports Science, 24(4), 355366.

https://doi.org/10.1080/02640410500131944

Taylor, J., \& Demick, A. (1994). A multidimensional model of momentum in sports. Journal of Applied Sport Psychology, 6(1), 51-70.

https://doi.org/10.1080/10413209408406465

Vallerand, R.; Colavecchio, P., \& Pelletier, L. (1988). Psychological momentum and performance inferences: A preliminary test of the antecedents-consequences psychological momentum model. Journal of Sport and Exercise Psychology, 10(1), 92-108.

https://doi.org/10.1123/jsep.10.1.92

Vicente-Vila, P. (2012). La influencia del portero-jugador en la eficacia ofensiva de un equipo de fútbol sala. Futbol pf: Revista de Preparacion Física en el Futbol, 5(1), 2943.

Vicente-Vila, P., \& Lago-Peñas, C. (2016). The goalkeeper influence on ball possession effectiveness in futsal. Journal of Human Kinetics, 51(1), 217-224. https://doi.org/10.1515/hukin-2015-0185

Vieira, I. (2010). Análisis de la importancia ofensiva de la figura del portero-jugador. Estudio de los partidos de cuartos de final de la Copa de España de fútbol sala 200809. Paper presented at the III Congreso Internacional de Ciencias del Deporte $y$ Educación Física. Universidad de Vigo. Pontevedra. (978-984). Sportis Formación Deportiva.

Villarejo, D.; Ortega, E.; Gómez, M., \& Palao, J. (2014). Design, validation, and reliability of an observational instrument for ball possessions in rugby union. International Journal of Performance Analysis in Sport, 14(3), 955-967. 